\title{
An evaluation of a microcomputer information system for leprosy control two years post-implementation
}

\author{
D CAMPOS-OUTCALT \\ Department of Family and Community Medicine, University of \\ Arizona, 1501 North Campbell Avenue, Rm 4335, Tucson, AZ \\ 85724, USA
}

\begin{abstract}
Accepted for publication 21 June 1990
Summary As part of a national programme to improve the management of health services in Papua New Guinea, a microcomputerized information system was designed and implemented in seven provinces. Four other provinces later adopted this system. One component of this information system was a program to assist disease control officers to monitor the treatment received by leprosy and tuberculosis patients.

In contrast to other components of the information system, the leprosy and TB computer program was not maintained nor used af ter two years. This article describes the computer program developed and discusses possible reasons for its nonuse.
\end{abstract}

\section{Introduction}

The worsening financial situation in many developing countries has resulted in a decrease of funds available for health care services. This has caused an increased emphasis on managerial efficiency in order to make constrained financial resources go farther. Improved management of health care programmes depend upon better utilization of available sources of data to point out problem areas and indicate where resources can best be applied.

Microcomputers have been advocated and applied in many development programmes as a means of improving the quality, quantity, timeliness and usefulness of data available to health care managers. ${ }^{\prime}$ Microcomputers have been applied as an information management tool to analyse rapidly population surveys, ${ }^{2,3}$ to monitor immunization coverage, ${ }^{4,5}$ to inventory drug supplies, ${ }^{6}$ and to assist in management of decentralized provincial health departments. ${ }^{7}$ Revanker, Gugal \& Sorensen have described a microcomputer system to assist in the management of leprosy programmes. ${ }^{8}$

Most publications describing the use of microcomputers in developing countries have been written shortly after the development and implementation of information management projects. There has been relatively little written about the long-term durability and maintenance of these information systems. 
This article will describe the results of a two-year follow-up evaluation of a microcomputerized information system developed for the management of leprosy and tuberculosis programmes in provincial divisions of health in Papua New Guinea.

\section{Description of the information systems}

During 1986 and 1987, a project funded by the Asian Development Bank (ADB) was aimed at improving the management of health programmes in seven provinces in Papua New Guinea. This project was a component of a national programme to improve the management of health services under a decentralized system where the provincial departments of health were given administrative responsibility for most health programmes. $^{9}$

Microcomputerized information systems were designed and implemented in the seven provinces which were included in the ADB project. The details of the information system and the types of reports available as well as the various stages of implementation, training and on-going management support to increase the use of the information produced, have been described elsewhere. ${ }^{7}$

The hardware in each province consisted of two IBM XT compatible microcomputers with 8088 processors, $640 \mathrm{~K} \mathrm{RAM}, 20$-mbyte hard disks and single $5 \cdot 25$-inch disk drives. The two computers shared a dot matrix printer. The main power supply was linked to a voltage regulator and stand-by power supply. The initial hardware cost, per province, was approximately US $\$ 5000$ and came from the ADB project budget. On-going maintenance and supplies was estimated to cost $\$ 2000-3000$ per year which was a provincial health department responsibility.

The software programs were developed using D-base III and D-base III + . While the usefulness of the various programs is limited for other countries, since they were developed to suit the specific circumstances of Papua New Guinea, they are available from the author. The author was involved with designing the reports, graphs and tables, testing and refining the software programs and providing management support and training to the provinces.

One component of the provincial information system was a program to assist disease control officers to monitor the treatments received by leprosy and tuberculosis patients. This system was very similar to the one developed in India and described by Revanker $e t$ $a l .{ }^{8}$ It allowed for individual patient monitoring and feedback to treatment centres. The information entered on each patient included name, age, treatment centre, date treatment started, reason treatment started (new patient, relapse, relocated) type of disease (multibacillary, paucibacillary), date treatment stopped and reason for stopping. Estimated ages, rather than date of birth, was used because people in PNG commonly do not know the latter.

A series of reports could be produced from this information and are described in Table 1. By using the microcomputer, each individual leprosy patient could be tracked through completion of treatment. A reminder system was built in to indicate when it was past time to end therapy. Reports were available to allow provincial disease control officers to compare the patients registered with the treatment cards at each treatment centre. End-ofthe-year analyses reports, tables and graphs offered the opportunity to study disease trends throughout the province. 
Table 1. Reports available for the leprosy control computer programs

Reports $\begin{gathered}\text { Information } \\ \text { available }\end{gathered}$

1. Monthly and year-to-date summary.

This could be produced monthly and provide a running total for the year.

The December report could be used as a final annual summary.

2. Patient list

3. Reminder list

4. Lost and transferred patients

5. End-of-year analysis
Treatment centre, district and provincial totals of patients starting treatment, ending treatment and overall totals by type of disease.

A list of all patients on treatment for each treatment centre including all information collected on each patient.

A list of all patients whose treatment should have been completed by the date of the report.

A list of all patients reported to be lost or transferred out to other treatment centres, and transferred in.

Incidence and prevalence rates for each treatment centre, district and the entire province. Individual age and sex breakdown with bar graphs to illustrate.

Details of the different levels of the health care system in Papua New Guinea have been published previously. ${ }^{10}$ The population of the provinces involved in the ADB project ranged from 60,000 to 300,000 . The reported leprosy prevalence rate ranged from a high of 5.8 per 1000 to a low of 1.8 per $1000 .{ }^{11}$ The number of new cases of leprosy reported ranged from 10 to 85 and the number of existing cases ranged from 186 to 687 . The reports received from treatment centres were monthly summaries of totals with no individual patient information. Supervisory visits were made periodically by disease control officers to treatment centres to review treatment cards but financial constraints had made this an increasingly rare occurrence.

In most provinces, disease control officers were health extension officers who had worked their way up into a supervisory position af ter having served in health care centres. Health extension officers receive 3 years of training and one year of supervised practice following completion of grade 10 or 12. Disease control officers were responsible for both the provincial TB and leprosy programmes. In addition to the disease control officers, provincial health departments had supervisors of other programmes such as maternalchildhealth, environmental health, water supply and nutrition. All reported to the provincial assistant secretary of health who was a medical officer or health extension officer.

Multidrug therapy was being tried in two of the seven provinces. The initial response of the disease control officers to the microcomputer programs was enthusiastic. New information collection forms were developed in the provinces to collect information on all patients starting and ending treatment. During a three week, on-site training programme, the local provincial health department personnel were shown how to enter data and produce reports. Follow-up visits by the management support team were made to assist in the interpretation of reports, tables and graphs. By the end of the project, the entire microcomputer information system had been installed and was functioning in all seven provinces. 


\section{Follow-up}

In May of 1988, a follow-up evaluation was conducted. The microcomputer system had been in place from one to two years in all seven provinces. In the ensuing time period, four more provinces had adopted the system, making 11 out of 20 provinces with computerized information systems. Multidrug therapy had been expanded to all provinces and management support activities out of the national office, including periodic provincial visits, had continued.

A standardized evaluation tool was developed to determine if: 1, the information in the system was being kept up to date; 2 , the reports were being produced and disseminated to programme managers; 3 , the information was being used for management decisions.

Evaluation information included: a structured questionnaire for provincial programme supervisors; the actual reports themselves to check for their availability, frequency of production and use; and annual reports, budget documents or other reports submitted to provincial governments.

The extent of use of the information system was categorized into three levels: considerable; some; none. If the supervisor stated that they used the programme, could give examples of its use and there was evidence of its use (provincial or divisional reports with data, objectives set and progress toward objectives known, computer reports in files with marks indicating analysis, etc.) then the extent of use was classified as considerable. If the supervisor stated they used the information and there was minimal evidence of its use, the extent of use was classified as some. If the supervisor stated they did not use the information or if there was no evidence of its use, the extent of use was classified as none.

\section{Results}

Table 2 describes the results of the evaluation on the use of the information system for four categories of supervisors in the provinces. The disease control officers were using the system far less often than the others. In only two of eleven provinces was the TB/leprosy information system usage judged to be considerable. In none of the provinces was the TB/ leprosy data up-to-date. In most provinces little data had been entered since the initial training sessions.

Table 2. Extent of utilization of the information system

\begin{tabular}{lcccc}
\hline & & \multicolumn{3}{c}{ Extent of use } \\
\cline { 3 - 5 } Supervisor of: & $\begin{array}{c}\text { No. } \\
\text { evaluated }\end{array}$ & Considerable & Some & None \\
\hline Maternal and child health & 10 & 8 & 1 & 1 \\
Nutrition & 8 & 5 & 1 & 2 \\
Water supply & 8 & 5 & 0 & 3 \\
TB/leprosy & 11 & 2 & 2 & 7 \\
\hline
\end{tabular}




\section{Discussion}

In contrast to most of the provincial information system, where the maintenance and use of the system over two years was found to be fairly good, the computer program developed for TB/leprosy control had largely fallen into disuse. There were four hypotheses developed to explain this:

1 Multiple drug therapy (MDT) was being introduced into the provinces at the same time as the computerized information system. While the system was developed to assist the disease control officer to manage MDT patients better, the increased work load of implementing MDT might have detracted from the efforts needed to maintain the information system.

2 The TB/leprosy computer program was part of an overall provincial health information system. It was one component which required entry of individualized patient information; most other components required the entry of monthly totals only. Access to the computer for data entry might have been a problem. In most provinces, the information system was operated by an information officer who received data from each of the individual programs. The information officers might have given preference to programs which required less data entry. However, no evidence was found that the TB/leprosy programmes were generating data which were not being entered into the computer; little to no data were being collected.

3 The component of the information system developed for the TB/leprosy programmes was developed based on data which were not routinely collected. There were two components of the entire provincial health information system which the follow-up evaluation showed to be underused; both depended on sources of information which were not being routinely collected by the provincial divisions of health at the time the computer system was developed. One of these was the TB/leprosy programme which depended upon new, individualized, patient data where only treatment centre summaries had been collected before; the other was a divisional personnel system with no method of systematically updating individual files. Both these components of the information system would have been a valuable addition to the management tools of the divisions of health; their potential value was not questioned. They were, however, impractical because the flow of information needed to maintain them was not a well established pattern.

4 The computer did not make the job of the disease control officers easier. They continued to collect and hand tally monthly treatment centre summaries in order to meet national reporting requirements (even though this could have been done automatically on their computer had the data been kept up-to-date). The computer system required new information to be collected and data entry to occur. While the individualized patient information would have helped the disease control officer better track the care provided at treatment centres (especially in the light of infrequent supervisory visits) there was added work necessary to obtain the information.

Microcomputers can be a useful addition to the management tools used in developing countries. They can make collection, storage, analysis and usage of information for management more efficient. It does, however, require considerable effort and moderate cost to start-up such systems and to train national staff to operate them. Start-up costs 
often come from external funding sources although in PNG several provinces purchased their own hardware and several more were considering this option. To create a favourable cost-benefit ratio, it is important to create computer programs which are useful and practical and which can be sustained. From the PNG experience, these recommendations can be made for those developing computer-based information systems in developing countries: 1, Do not try to use the computers to create new information systems; use them to make existing systems more efficient and informative; 2, allow any newly desired information to be collected manually for a specified time period to see if it is practical and useful and if the information can be collected dependably; 3, Do not introduce too many programme components at one time (i.e., MDT, new information collection, computer systems).

At the end of the evaluation, a recommendation was made to the national Department of Health to design a TB/leprosy component for the provincial information system based on the long-established monthly treatment centre summaries and to retain the system designed for individual patient data on the computer to be used by those interested.

\section{References}

${ }^{1}$ Berge N, Ingle MD, Hamilton M. Microcomputers in development, a manager's guide. Kumarian Press, West Hartford, Connecticut, 1986.

2 Frerichs RR. Simple analytic procedures for rapid microcomputer-assisted cluster screenings in developing countries. Public Health Rep, 1989; 104: 24-35.

${ }^{3}$ Frerichs R R, Tar KT. Computer-assisted rapid surveys in developing countries. Public Health Rep, 1989; 104: 14-23.

4 Babikir A, Dodge CP, Pett I. Monitoring immunization coverage in the Sudan. Health Policy Plan, 1989; 4: 91-5.

5 Frerichs RR, TarK T. Use of rapid survey methodology to determine immunization coverage in rural Burma. J Trop Pediatr, 1988; 34: 125-30.

6 Hogerzeil HV, Manell P. Computerized drug supply systems for developing countries. Health Policy Plan, 1989; 4: 177-81.

7 Campos-Outcalt D, Vickers P. For fuller utilization of health data. World Health Forum, 1988; 9: 405-8.

8 Revanker CR, Goyal N, Sorensen BH. Management information system for leprosy eradication programme-an alternative information system. Le pr Rev, 1989; 60: 129-34.

9 Newbrander WC, Thomason JA, Kolehmainen-Aitken RL, et al. Management support for provinces: A programme for developing provincial health management capabilities in Papua New Guinea. Int J Health Plan Manag, 1988; 3: 45-55.

10 Campos-Outcalt D. Health services in Papua New Guinea. Public Health, 1989; 103: 161-9.

11 Papua New Guinea National Health Plan 1986-1990. Department of Health, Boroko, Papua New Guinea, 1986. 


\title{
Une évaluation d'un système d'information de micro-ordinateur pour le controle de la lèpre deux ans après sa mise en pratique
}

\author{
D CAMPOS-OUTCALT
}

Sommaire - Comme partie d'un programme national pour améliorer l'administration des services sanitaires en Papouasie-Nouvelle-Guinée, un système micro-informatique d'information a été conçu et mis en pratique en sept provinces. Le système a été adopté postérieurement par d'autres quatre provinces. L'un des élements de ce système d'information c'était un programme pour aider aux agents de contrôle des maladies à contrôler les traitements reçus par des patients de lèpre et de tuberculose.

Par contraste avec les autres élements du système d'information, le programme informatique pour le contrôle de la lèpre et la tuberculose n'a pas été maintenu ni utilisé après deux ans. Cet article décrit le programme développé et discute des possibles raisons pour lesquels il n'a pas été utilisé.

\section{Una evaluation de un sistema de informacion de microordenador para el control de la lepra dos años despues de su ejecucion}

\section{CAMPOS-OUTCALT}

Resumen - Como parte de un programa nacional para mejorar la administración de los servicios de sanidad en Nueva Guinea Papúa, se diseñó un sistema de información a base de microordenadores que fué puesto en práctica en siete provincias. Posteriormente adoptaron el sistema cuatro provincias más. Uno de los componentes de este sistema de información era un programa diseñado para asistir a los agentes de control de enfermedades a controlar los tratamientos que recibían los pacientes de lepra y de tuberculosis.

En contraste con los otros componentes del sistema de información, el programa para el control de la lepra y de la tuberculosis no se mantuvo ni seguía en uso al cabo de dos años. Se describe en este artículo el programa de ordenador desarrollado y se discuten posibles razones por las cuales no se utilizó. 